\title{
Retinal and Choroidal Blood Flow in Unstressed Fetal and Neonatal Lambs
}

\author{
LOUIS L. H. PEETERS." RO(II:R LE. SHIEII)ON M. I)OU(ILAS JONES. JR. \\ ANI) IRI:DERICK ( B BATIACIILA

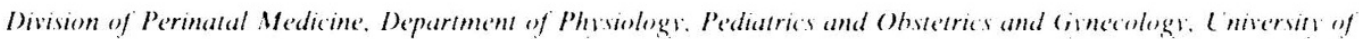 \\ Colorade Mledical (enter. Denver. Colorade. I'St
}

\begin{abstract}
Summary
The relationship between retinal blood flow ( $R B F$ ) and choroidal blood flow ( $\mathrm{ChBF}$ ) and the oxygen content of arterial blood was investigated in 12 fetal lambs. The postnatal changes in these flows were studied in twelve newborn lambs. $\mathrm{RBF}$ and $(\mathrm{hBF}$ were determined by means of radioactive microspheres 3 to 10 days after implantation of the injection and sampling catheters. Fetal blood flows were measured at different levels of oxygenation. The postnatal flows were measured while the lamb breathed room air. The fetal data suggest an inverse relationship between $R B F$ and arterial oxygen content. Concomitant changes in fetal ( $h B F$ were unrelated to arterial oxygen content. Because of the inverse relationship between $\mathrm{RBF}$ and arterial oxygen content, the product of RBF and arterial oxygen content was independent of the state of fetal oxygenation.
\end{abstract}

RBF did not change with birth, whereas $C h B F$ increased. There was no change in $R B F$ with postnatal age whereas $C h B F$ decreased significantly with increasing age.

\section{Speculation}

A reduced vascular resistance in the immature choroid might be an important predisposing factor in the development of retrolental fibroplasia in preterm babies treated with high environmental oxygen.

There has been considerable interest in the regulation of retinal and choroidal blood flow as a result of the association of oxygen toxicity and retrolental fibroplasia (9). Dollery et al. (6) proposed a model by which excessive constriction of immature retinal vessels might be produced by an increase in tissue $\mathrm{PO}$.. In their study, however, a number of assumptions made about the retinal and choroidal circulations were derived from acute experiments in anesthetized animals in which physiologic reactance (18) might have altered retinal and choroidal physiology. The goal of the present study was to describe the relationships observed under chronic experimental conditions between the fetal retinal and choroidal blood flows and oxygen contents ower a wide range and changes in these flows with postnatal age.

\section{MATERIALS AND METHIOLS}

Twelve pregnant ewes of mixed western breed at 130 to 145 days of gestation and 12 newborn lambs in the first 5 months after birth were studied. Surgery was performed under pentobarbital sedation $(5 \mathrm{mg} / \mathrm{kg})$ and. in the ewes, also spinal anesthesia $(8 \mathrm{mg}$ tetracaine hydrochloride). As described previously for fetal lambs (12), polyvinyl chloride catheters (ID). $0.9 \mathrm{~mm}$. OD. $1.2 \mathrm{~mm}$ ) were inserted into a transverse scapular artery, a pedal vein, both pedal arteries. and the amniotic sac. In newborn lambs, the catheters were inserted into a transverse scapular artery, the left ventricle. and a femoral artery. The ends of the catheters in both fetal and newborn lambs were exteriorized via a $S C^{\prime}$ tunnel and stored in a pouch on the flank of the ewes and the newborn lambs. respectively.

\section{MFASUREMINTS IN HETLISIS}

Studies were carried out between the third and 10 th postoperative day. In each animal. three sets of flow measurements were performed by means of the microsphere technique $(3,11,14)$ at different levels of fetal oxygenation. Microspheres of $15 / \mathrm{m} \mathrm{di-}$ ameter (3M Co.. St. Paul. MN) labeled with either " ( $r$. " (e. or ${ }^{*} \mathrm{Sr}$ were used. (hanges in fetal oxygenation were induced by exposing the ewe to varying concentrations of oxygen (10 to

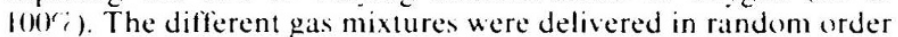
at high flow rates into a large plastic bag that completely enclosed the head of the ewe. To atlain steady-state conditions in fetal oxygenation and cardiovascular function at each gas mixture. a minimum of $30 \mathrm{~min}$ was allowed for equilibration. Fetal arterial blood pressure ( $\mathrm{B}$ B ; torr) defined in this study as the difference in mean pressure between the fetal abdominal aorta and the amniotic sac, and fetal heart rate (FHR; beats/min) were monitored throughout the experiment. Blood llow measurements were performed when stable FBP and FHR had been recorded for at least $20 \mathrm{~min}$. At the time of each flow measurement. blood samples were collected from each of the arterial catheters for measurements of $\mathrm{pH} . \mathrm{PC} \mathrm{O}_{2}, \mathrm{PO}_{2}$ (at $39.5^{\circ} \mathrm{C}$ by means of Radiometer $\mathrm{BMS} 3$ MK2). O, content. (by means of the Lex-O-con), and hematocrit (microcapillary technique). Return to pre-experimental values of both FHR and FBP always occurred after completion of the experiments. The ewe was then sacrificed. and the fetus was delivered by cesarian section. ('atheter positions were checked at autopsy. All fetal organs were dissected as described previously (14).

The eyes were enucleated. and separate samples of choroid and retina were obtained by way of the dissection procedure described by $\mathrm{Alm}$ and Bill (1). The tissue samples were dried for $24 \mathrm{hr}$ at $80^{\circ} \mathrm{C}$. weighed. and $\gamma$-radiation was determined with a gamma counter (Nuclear (Chicago three-channel autogamma). In three fetal lambs dry weight/wet weight ratios were determined for both retinal and choroidal tissue. For hoth tissues the dry weight/wet weight ratio was $-0.2(0$, in agreement with observations reported in the literature (1).

For the flow calculations, it was assumed that a dry weight/wet weight ratio of $\sim 0.2()$ applied to retinal and choroidal tissue throughout the perinatal period studied.

Blood flow to both retina and choroid was calculated according to the following equation:

$$
\mathrm{TBF}=\frac{\left(\mathrm{PM}_{1 .} \times \mathrm{ts} \cdot \mathrm{DrW}\right.}{\left(\mathrm{PM}_{\mathrm{r}} \times 0.20\right.} \times \mathrm{F}_{\mathrm{H}}
$$

where $\mathrm{TBF}=$ tissue blood flow $\left(\mathrm{ml} \cdot \mathrm{min}^{\prime} \cdot 100 \mathrm{~g}^{1}\right), \mathrm{CPM}_{1}=$ total $\mathrm{cpm}$ in the tissue sample. $\left(\mathrm{PM}_{1}=\mathrm{cpm}\right.$ in the arterial reference sample. ts. DrW $=$ dry weight of the tissue sample. and 
$F_{1}=$ the sampling rate of the withdrawal pump $\left(1.28 \mathrm{ml} \cdot \mathrm{min}^{\prime}\right.$ in each experiment).

Calculations showed that the retinal samples always contained $\geq 200$ microspheres of a particular label whereas arterial reference samples and choroidal samples always contained $\geq 800$ microspheres. The relatively large variability in retinal blood flow was due. in part. to the low number of spheres in the retinal tissue samples (3). The injection of a higher total dose of microspheres would have reduced this variability, at the expense, however. of more interference with fetal physiology (2.19).

\section{MEASUREMLNTS IN NEWBORN I.AMBS}

The newborn lambs were studied between the second and fifth postoperative days. Their postnatal age at the day of experimentation ranged between 2 and 226 days. In most instances. flow measurements were made with the newborn lamb sitting quietly in a large cardboard box breathing room air. To reduce potentially disturbing factors such as excessive light or noise, the cover of the box was loosely closed. and the ends of the three catheters were brought outside through a hole in the top of the box. Blood flow measurements were performed as described for fetal lambs. At the time of each flow measurement, the arterial blood pressure (torr) was measured as the difference in height between the fluid level in the transverse scapular arterial catheter and the xiphoid process. After the third microsphere injection. the newborn lambs were sacrificed. and tissue was processed as described for the fetal lambs.

\section{DATA ANALYSES}

For fetal lambs, the relationship between blood tlow and oxygen content in the ascending aorta $\left([\mathrm{O}]_{n}: \mathrm{mM}\right)$ for both retina and choroid was analyzed as follows. In general. three blood flow values were obtained from each animal. A mathematical model was chosen for the description of the flow-oxygen relationships for the retina and choroid which allowed each animal to have its own "animal effect" whereas the empirical equation was identical for each of the twelve animals studied. A major advantage of this approach over an analysis based on pooled data is that the effect of oxygen on organ flow can be analyzed. whereas possible effects of differences between animals, particularly those due to systematic experimental error, are filtered out. The flow-oxygen relation for both the retina and the choroid could be described by the general equation:

$$
\underline{y}_{i i}=\mu+\alpha_{1}+\beta f\left(\gamma, x_{11}\right)+\underline{e}_{i j}
$$

where $\underline{y}_{11}=$ flow measurement in the $j^{\text {th }}$ experiment on the $i^{\text {th }}$ animal: $\mu=$ a constant. identical for all animals; $a_{1}=$ additive "animal correction factor" due to the $i^{i \text { th }}$ animal. (Correction factor $\alpha$ was determined in such a way that the sum of the twelve values for a equaled zero): $\beta, \gamma=$ regression coefficients, assumed to be the same for all animals: $x_{11}=$ value of $\left[\mathrm{O}_{2}\right]_{\text {it }}$ in the $\mathrm{j}^{\text {th }}$ experiment on the $i^{\text {th }}$ animal: $f\left(\gamma, x_{11}\right)=$ transform of $x_{i j}$ and $\gamma\left(e, g . f\left(\gamma, x_{11}\right)\right.$ $=\mathrm{e}^{* 11}$. etc.): $\underline{\mathrm{e}}_{11}=$ error term with expectation of zero and standard deviation proportional to the expectation of $y_{11}$.

The mathemathical elaboration associated with the analysis described above is given in detail in the appendix to this report and is termed "weighted least-squares method" in the remainder of this publication.

\section{RISUITS}

\section{H.THI ST(T)Y}

The flow data and concomitant arterial parameters in the twelve fetal lambs used in this study are listed in Table 1. For reasons mentioned elsewhere (13). O- content rather than PO, was used as index for oxygenation in the flow-oxygen relationships studied. The relationship between $\mathrm{RBF}$ and $\left[\mathrm{O}_{2}\right]_{1,}$ is presented in Figure 1 . By the weighted least-squares method. a number of mathematical

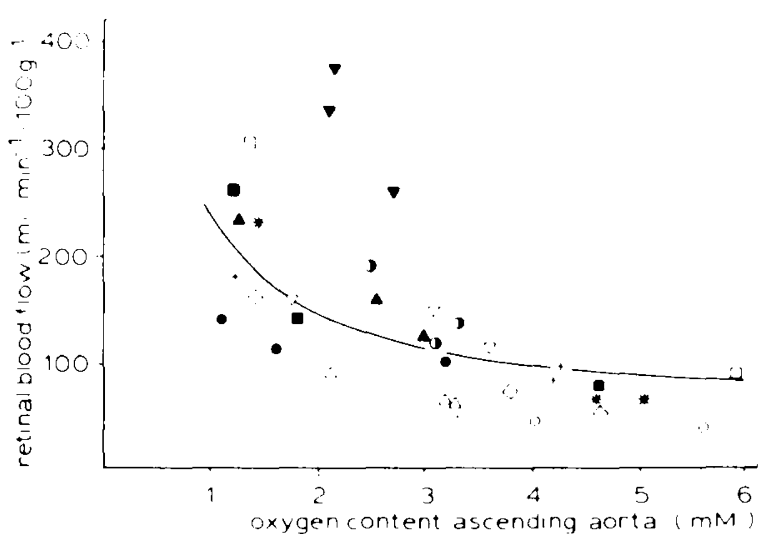

Fig. 1. Relationship between fetal $\mathrm{RBF}$ and $[0]_{\text {. }}$ in the ascending aorta. The flow data of different animals are represented by 12 different symbols. Lime is calculated using the reciprocal function for an animal with animal effect $a=0$ (see text).

functions were evaluated as to their adequacy to describe the $\mathrm{RBF}-\left[\mathrm{O}_{2}\right]_{\text {; }}$ relation. The results summarized in Table 2 suggest that some nonlinear function describes that relationship best. However. no clear discrimination could be obtained between the three nonlinear functions tested. In other fetal neural structures such as cerebrum, brain stem, and cerebellum, it has been demonstrated that the flow-oxygen relation was best described by a reciprocal function (15). Therefore. it was assumed that a reciprocal function might best describe the flow-oxygen relation for the fetal retina. Consequently the following equation was selected:

$$
\mathrm{RBF}=\mu+\beta^{1} /\left[\mathrm{O}_{2}\right]_{\mathrm{i}}+\alpha
$$

By the weighted least-squares method, the parameters in equation 3 were calculated:

$$
\mathrm{RBF}=-55+1981 /\left[\mathrm{O}_{2}\right]_{: 1}+\alpha
$$

In this and all subsequent equations, blood flow is in $\mathrm{ml} \cdot \mathrm{min}{ }^{1}$. $100 \mathrm{~g}$. The additive animal effect a ranged from 0 to +233 . According to the weighted least-squares method, approximately 82 "' of the intra-animal variability in RBF could be explained by changes in $1 /\left[\mathrm{O}_{2}\right]_{: \text {. }}$.

Equation 4 can also be expressed as follows:

$$
\mathrm{RBF} \cdot[\mathrm{O} \cdot]_{14}=198+\left[\mathrm{O}_{2}\right] \cdot(a-55)
$$

The equation expresses the relationship between the flow of $\mathrm{O}_{2}$ to the fetal retina ( $\mu$ moles $\left.\cdot \min { }^{\prime} \cdot 100 \mathrm{~g}{ }^{\prime}\right)$ and the $\left[O_{2}\right]_{\ldots}$. We were not able to demonstrate a significant correlation between the flow of oxygen to the fetal retina and the level of fetal oxygenation (sign test. $P>0.1$ ).

The relationship between choroidal blood flow ( $\mathrm{C} h \mathrm{BF})$ in $\mathrm{ml}$. $\min { }^{\prime} \cdot 100 \mathrm{~g}^{\prime}$ ) and $\left[\mathrm{O}_{2}\right]_{i}$ is presented in Figure 2. Analysis of this relationship by the weighted least-squares method indicated

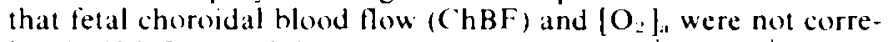
lated. $C h B F$ ranged from $9(0)$ to 3700$) \mathrm{ml} \cdot \min { }^{1} \cdot 100 \mathrm{~g}$ ? with a mean for all fetal data points combined of $1620 \mathrm{ml} \cdot \mathrm{min}^{1} \cdot 100 \mathrm{~g}$ $( \pm 127$ S.E. $)$.

\section{NFWB(ORN STIII)Y}

The flow data and concomitant arterial parameters in the 12 newborn lambs studied are listed in Table 3. Inasmuch as the level of oxygenation was not altered in newborn lambs. no mathematic function could be constructed for the $\left.\mathrm{RBF}-\mathrm{O}_{2}\right]_{\text {in }}$ relationship. It is noteworthy. however. that the neonatal data seem to extend the trend shown by the fetal data points in the higher $\left[\mathrm{O}_{2}\right]_{\text {, }}$ range (Fig. 3). ChBl: was slightly higher in newborn lambs than in fetuses. The values for ( $\mathrm{hBF}$ ranged from 1550 to $3966 \mathrm{ml} \cdot \mathrm{min} \cdot 100 \mathrm{~g}$ with a mean of $2700 \mathrm{ml} \cdot \mathrm{min}^{\prime} \cdot 100^{\prime}( \pm 160 \mathrm{~S}$. E.). Comparison of the mean ( $\mathrm{hBF}$ before and after birth indicated that this value 
Table 1. Retinal and choroidal hlood flow's with the concomitant values for $F B P$, as well as $P O_{2,}, P C O ., 2 H$, and $/ O_{2 /,}$ in the ascending aorta of the I2 fetal lambs

\begin{tabular}{|c|c|c|c|c|c|c|c|c|}
\hline $\begin{array}{l}\text { Identifying } \\
\text { symbol }\end{array}$ & $\begin{array}{c}\text { Experiment } \\
\text { no. }\end{array}$ & $\begin{array}{c}\mathrm{RBF} \\
(\mathrm{ml} \cdot \mathrm{min} \\
\left.100 \mathrm{~g}^{\prime}\right)\end{array}$ & $\begin{array}{c}\text { ChBF } \\
(\mathrm{ml} . \mathrm{min} \\
\left.100 \mathrm{~g}^{\prime}\right)\end{array}$ & $\begin{array}{l}\mathrm{FBP} \\
\text { (torr) }\end{array}$ & $\begin{array}{l}{\left[\mathrm{O}_{2}\right]_{4}} \\
(\mathrm{mM})\end{array}$ & $\begin{array}{l}\mathrm{PO}_{2} \\
\text { (torr) }\end{array}$ & $\begin{array}{l}\mathrm{PCO}= \\
\text { (torr) }\end{array}$ & $\mathrm{pH}$ \\
\hline & 1 & & & & 4.06 & 23 & 38 & 7.44 \\
\hline \multirow[t]{3}{*}{0} & 2 & 37 & 1312 & & 5.58 & 36 & 44 & 7.38 \\
\hline & 3 & 45 & 1042 & & 4.102 & 23 & 39 & 7.44 \\
\hline & 1 & 189 & 2930 & & 2.50 & 18 & 47 & 7.36 \\
\hline \multirow[t]{3}{*}{ ( } & 2 & 137 & 2249 & & 3.30 & 21 & 47 & 7.37 \\
\hline & 3 & 117 & 1495 & & 3.08 & 21 & 48 & 7.36 \\
\hline & 1 & 115 & 1551 & & 1.61 & 18 & 42 & 7.34 \\
\hline \multirow[t]{3}{*}{$\bullet$} & 2 & 141 & 2036 & & 1.07 & 14 & 40 & 7.24 \\
\hline & 3 & 100 & 3626 & & 3.21 & 26 & 43 & 7.30 \\
\hline & 1 & 116 & 2264 & 46 & 3.61 & 23 & 42 & 7.37 \\
\hline \multirow[t]{3}{*}{$V$} & 2 & 161 & 1550 & $4 x$ & 1.75 & 16 & 35 & 7.33 \\
\hline & 3 & 150 & 1897 & 47 & 3.08 & 22 & 38 & 7.38 \\
\hline & 1 & 64 & 1354 & 37 & 3.17 & 25 & 44 & 7.38 \\
\hline \multirow[t]{3}{*}{$\triangle$} & 2 & 89 & 931 & 36 & 2.11 & 21 & 42 & 7.36 \\
\hline & 3 & 62 & 927 & 38 & 3.21 & 29 & 46 & 7.37 \\
\hline & 1 & 258 & 1330 & 45 & 2.77 & 21 & 47 & 7.35 \\
\hline \multirow[t]{3}{*}{$\boldsymbol{\Lambda}$} & 2 & 374 & 1411 & 49 & 2.14 & 17 & 44 & 7.32 \\
\hline & 3 & 334 & 1596 & 47 & 2.10 & 18 & 41 & 7.37 \\
\hline & 1 & 124 & 1338 & 35 & 2.98 & 22 & 48 & 7.34 \\
\hline \multirow[t]{3}{*}{$\Delta$} & 2 & 234 & 1649 & 42 & 1.26 & 16 & 39 & 7.21 \\
\hline & 3 & 148 & 1721 & 34 & 2.56 & 20 & 47 & 7.34 \\
\hline & 1 & 85 & 1797 & 29 & 4.19 & 27 & 45 & 7.36 \\
\hline \multirow[t]{3}{*}{+} & 2 & 96 & 1725 & 28 & 4.24 & 28 & 50) & 7.31 \\
\hline & 3 & 179 & 2215 & 32 & 1.23 & 16 & 41 & 7.33 \\
\hline & 1 & 64 & 1065 & 28 & 5.03 & 28 & 38 & 7.45 \\
\hline \multirow[t]{3}{*}{${ }^{*}$} & 2 & 64 & 919 & 30 & 4.59 & 27 & 30 & 7.46 \\
\hline & 3 & 233 & 1666 & 41 & 1.45 & 18 & 26 & 7.23 \\
\hline & 1 & 62 & 1215 & 36 & $4.60)$ & 25 & 49 & 7.38 \\
\hline \multirow[t]{3}{*}{$\boldsymbol{Z}$} & 2 & 73 & 1049 & 36 & 3.80 & 27 & 46 & 7.35 \\
\hline & 3 & 162 & 1173 & 42 & 1.41 & 15 & 41 & 7.35 \\
\hline & 1 & 78 & 1244 & 40) & 4.64 & 25 & 54 & 7.32 \\
\hline \multirow[t]{3}{*}{$\boldsymbol{\square}$} & 2 & 141 & 1418 & 43 & 1.80 & 14 & 48 & 7.32 \\
\hline & 3 & 260 & 1728 & 51 & 1.21 & 12 & 38 & 7.26 \\
\hline & 1 & & & 50 & 6.62 & 30 & 47 & 7.27 \\
\hline \multirow[t]{2}{*}{ !.] } & 2 & 89 & 2141 & 52 & 5.84 & 25 & 42 & 7.42 \\
\hline & 3 & 303 & 2551 & 70 & 1.34 & 13 & 35 & 7.25 \\
\hline
\end{tabular}

Table 2. Mathe'matical functions evaluated for their adequacy in describing the $R B F$ oxigen relation

$\begin{array}{llcc}\text { Mathematical } & \text { Empiric } \\ \text { function } & \text { equation } & \begin{array}{c}\text { Estimate for } \\ \text { percentage } \\ \text { error }(\%)\end{array} & \begin{array}{c}\text { Degrees } \\ \text { of } \\ \text { freedom }\end{array} \\ \text { Linear function } & f(x)=\mu+\beta \cdot x & 21.0 & 22 \\ \text { Reciprocal function } & f(x)=\mu+\beta \cdot 1 / x & 19.0 & 22 \\ \text { logarithmic tunction } & f(x)=\mu+\beta \cdot \ln x & 18.3 & 22 \\ \text { Exponential function } & f(x)=\mu+\beta \cdot e^{2} & 18.6 & 21\end{array}$

was significantly higher in newborn lambs (Student $t$ test: $P<$ (o.01). The postnatal trend in blocod flow to both retina and choroid (Fig. 4) was evaluated as follows. The mean value for RBF and ( $h \mathrm{BF}$ was calculated for each newborn lamb. The Spearman Correlation coefficient (16) determined for the relationship between these mean values for $\mathrm{RBF}$ and $(\mathrm{hBF}$. with age, were $+0.17(\mathrm{df}=9: P>0.1)$ and $-0.62(\mathrm{df}=10: P<0.05)$, respectively. indicating no relationship between $\mathrm{RBF}$ and age, and a significantly decreasing $\mathrm{C} h \mathrm{BF}$ with postnatal age.

\section{DISCUSSION}

The curvilinear relationship between fetal $\mathrm{RBF}$ and $[\mathrm{O}]_{\text {. }}$ seemed to be described best by a reciprocal function. Such a relationship would not be surprising because in the same group of animals, the relationship between flow and oxygen in various

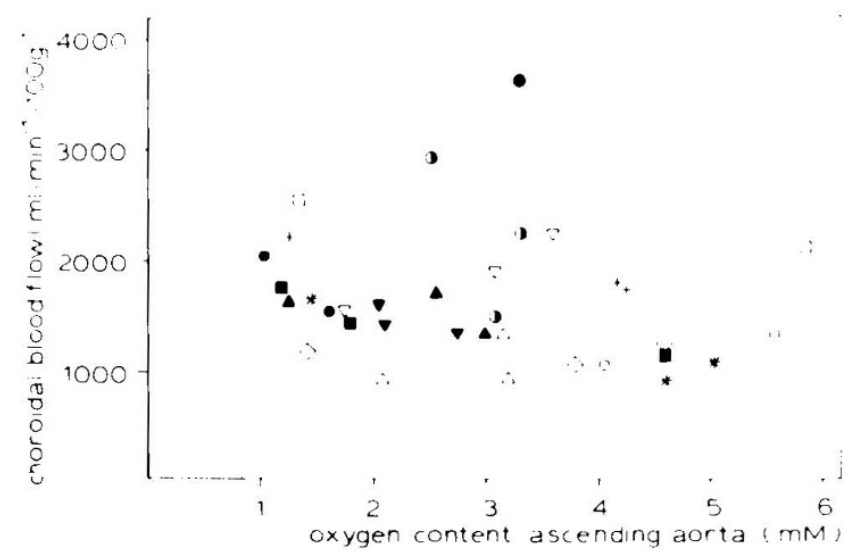

Fig. 2. Relationship hetween ( $\mathrm{hBF}$ and $[0$ ). in the ascending aorta. Flow data from different fetuses were identified by using the same 12 symbols as in ligure 1.

other central nervous system tissues was also best described by such a function (15). This similarity in flow response to changing levels of $\left[\mathrm{O}_{2}\right]_{\text {it }}$ in both fetal retina and central nervous svstem suggests that a similar mechanism regulates flow to both tissues when the $\left[\mathrm{O}_{3}\right]_{11}$ is altered. In the present study, $82^{\prime \prime} ;$ of the intraanimal variability in $\mathrm{RBF}$ could be explained by $1 /\left[\mathrm{O}_{2}\right]_{: \text {. }}$. The 
Table 3. Retinal and choroidal blood flows with the concomitant values for age, systemic BP. $P O_{2}, P\left(O_{2}, p H\right.$, and /O /, in the ascending aorla of the 12 newborn lambs

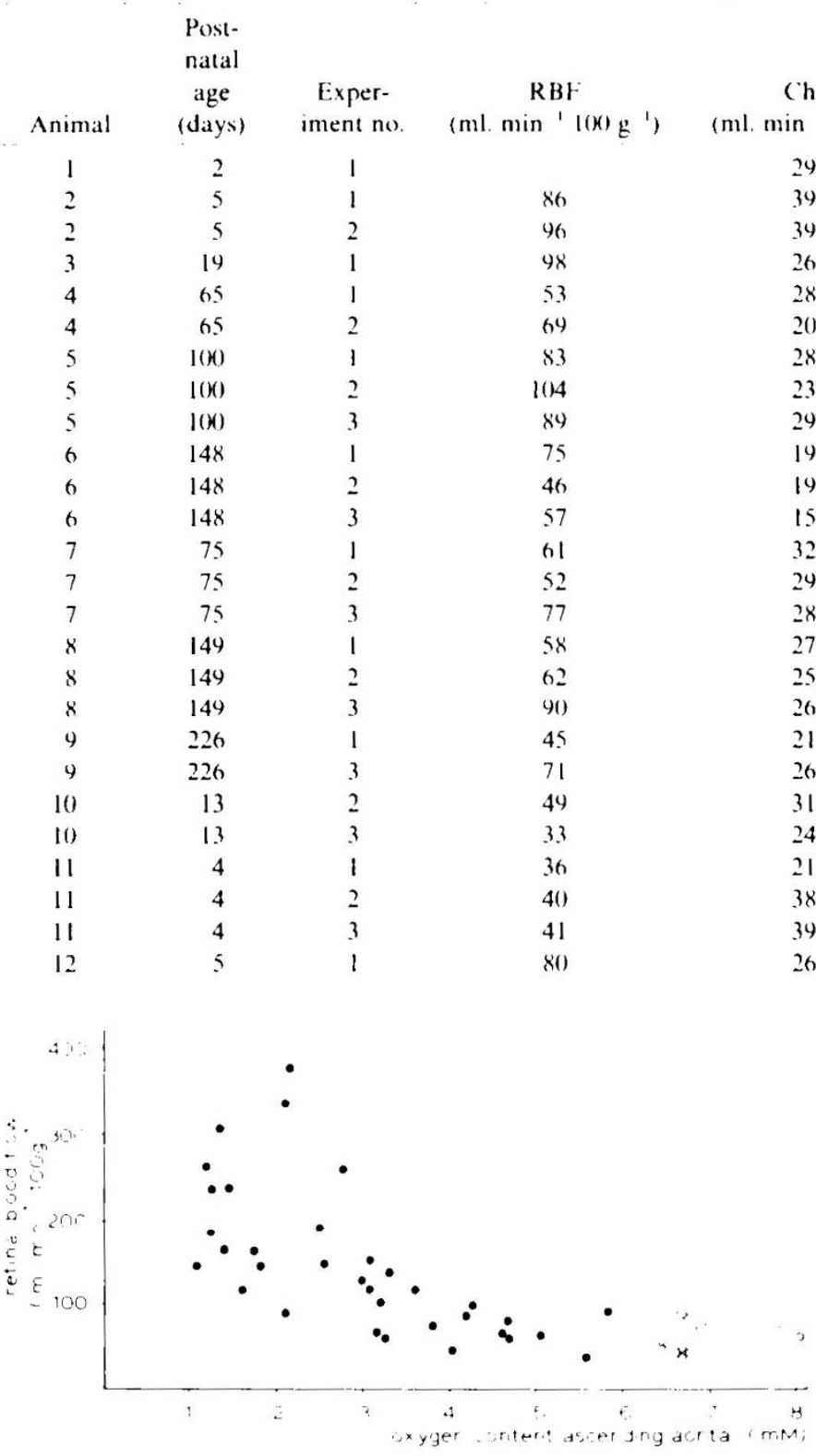

Fig. 3. Relationship of fetal (O) and neonatal ( ) RBF with $\{0$. . in the ascending aorta.

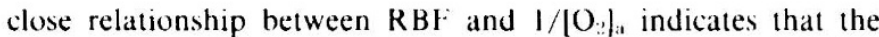
maintenance of oxygen delivery to the retina by way of the retinal vessels is carefully controlled over a wide range of oxygenation. However. it should be emphasized that the microsphere technique as used in this study did not permit assessment of regional flows and oxygen delivery to various areas of the retina. Rather. to have sufficient tissue (and therefore adequate numbers of microspheres) for quantitation. the retinal flow as a whole was studied. It is possible that the reciprocial relationship between $\mathrm{RBF}$ and $\mathrm{O}$ : content described for the retina as a whole, may not be true for a selected area (i.e.. the periphery).

To our knowledge. RBF in the fetus has not previously been measured. In adults, it is generally accepted that the arterial $\mathrm{PO}_{2}$ is an important flow-regulating factor in the retina $(6-8)$. However, it is still obscure whether $\mathrm{RBF}$ correlates better with $\mathrm{O}_{2}$-content or with $\mathrm{PO}$., in the supplying artery. In the present study, both $\left[\mathrm{O}_{2}\right]_{: a}$ and $\mathrm{PaO}_{2}$ were altered simultaneously. Thus, it was impossible to determine if one of the two indices for oxygenation correlated with fetal RBF better than the other. Jones et al. (10) found that cerebral blood flow in the fetal lamb correlated better
Mean systemic [O. $1 . \quad \mathrm{PO} 2 \quad \mathrm{P(O}$ $\begin{array}{llll}1 & 100 \mathrm{~g} ') & \text { (torr) (torr) } & \end{array}$

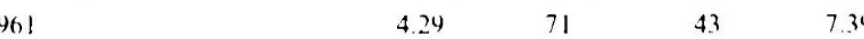

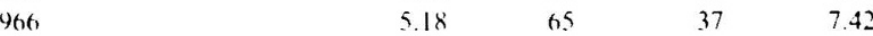
$\begin{array}{lllll}929 & 4.82 & 6.3 & 36 & 7.41\end{array}$ $\begin{array}{lllll}2613 & 5.27 & 70 & 37 & 7.41\end{array}$ 834 2033 2884

2363

2930

1920
1985

1550

3247

2451

2733

2547

26.58

2195

2619

2498

2130

3834

3924 6.34

79
80
79

6.52

6.65

6.34

6.65

6.70

6.92

6.70

6.88

8.14

7.6 .3

7.81

6.99

6.80

6.61

6.6 .3

6.33

6.67

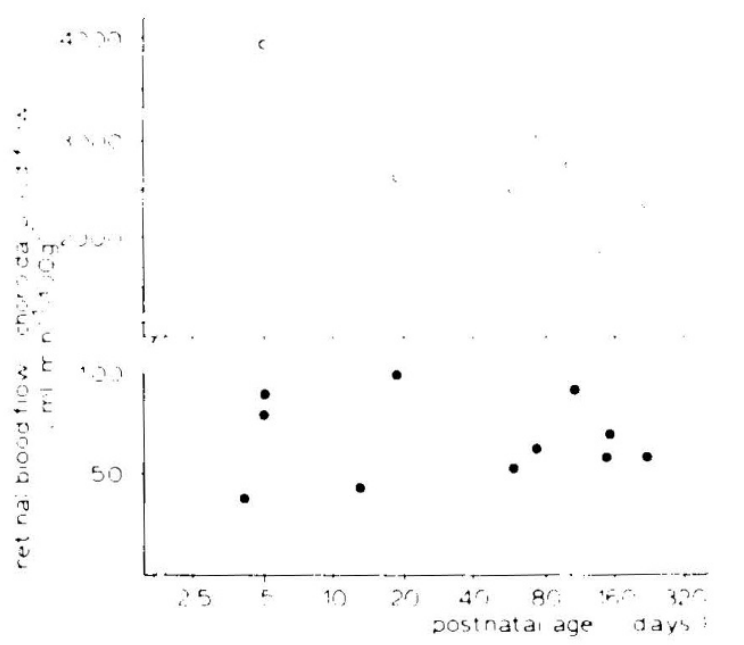

Fig. 4. Relationship of ( $h \mathrm{Bl}$ ( ) and $\mathrm{RBF}$ (O) with postnatal age. The ( hBF decreased significantly with postnatal age.

with $\left[\mathrm{O}_{2}\right]_{\text {, than }}$ with $\mathrm{PaO}_{-} \cdot\left[\mathrm{O}_{2}\right]$ is of fundamental importance to the organism. (ain (4) found that under circumstances of extreme oxygen deprivation in the adult, whole-body $\mathrm{O}$. uptake was determined by $\left[\mathrm{O}_{2}\right]_{: \text {r }}$ rather than $\mathrm{PaO}_{2}$. Although there is no such information avatiable for the retina. it is possible that $R B F$ responds directly to changes in $\left[\mathrm{O}_{\ldots}\right]_{\text {. }}$ Further investigations are required.

The range of $\left[\mathrm{O}_{2}\right]_{\text {a }}$ and $\mathrm{PaO}$ in the newhorn lambs was too small to permit conclusions about the flow-O relationships in the retinal circulation of the newborn. In the case of both [O. $]_{\text {. }}$ and $\mathrm{PaO}$. however. the neonatal data points appear to follow the trend established by the fetal tlow-O.: relationships in the higher ranges of $\left[\mathrm{O}_{2}\right]_{\text {ir }}$ and $\mathrm{PaO}$. (Figs. 3 and 5). Further experiments covering a wider range of $[\mathrm{O}]$, levels in the neonate are needed 


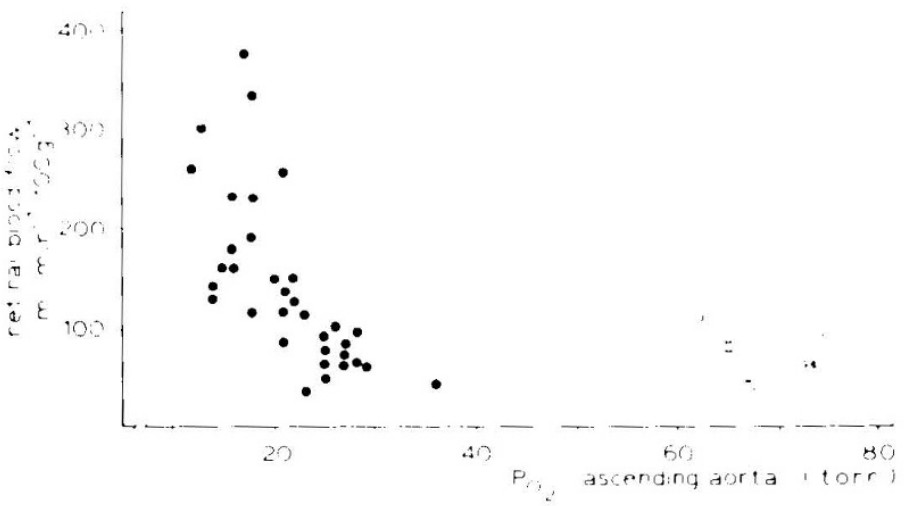

lig. 5. Relationship of fetal (O) and neonatal o $\mathrm{RBI}$ with the $\mathrm{PO}$ ) in the ascending aorta

to determine whether the flow-Oz relationship is the same during the fetal and newhorn periods.

It has been demonstrated that blood tlow in the adult retina changes markedly with variations in arterial $\mathrm{PCO}^{\circ},\left(\mathrm{PaC}^{\circ} \mathrm{CO}_{2}\right)(1$. 17). In the present study. the range of $\mathrm{PaCO}$.: in both fetal and neonatal lambs was too small to permit a conclusion about the presence of this relationship in these life phases.

Although fetal ( $\mathrm{hBF}$ was not correlated with $[\mathrm{O}]_{\ldots}$, some interesting phenomena were observed in the perinatal period. First. the blood flow to the choroid was significantly higher after birth. Inasmuch as the blood pressure is higher in the newborn (5). this might reflect a lack of autoregulation in this tissue structure, as has been reported for the adult animal by $\mathrm{Alm}$ and Bill (1). Second, in the first 5 months after birth. (hBF tends to decrease with age whereas systemic blood pressure has been reported to increase $(5,20)$ ). This suggests a delayed development of the ultimate "mature" vascular resistance in the choroidal vascular bed. One might speculate that. in comparison with the mature newborn state. the vascular resistance in the premature choroid is even lower and consequently blood tlow is higher at any given perfusion pressure. Such a high flow rate. logether with the absence of an $\mathrm{O}_{2}$-related flow regulating mechanism. would greatly favor the development of high local tissue oxygen tensions in premature babies treated with high environmental oxygen.

Clearly, further studies are needed both in terms of detining regional changes in $\mathrm{RBF}$ and ( $\mathrm{hBF}$ at various levels of oxygenation and also by alteration in $\mathrm{O}_{2}$ capacity, more sharply delineating the role of $\mathrm{PaO}_{2}$ versus $\mathrm{O}_{2}$ content in the regulation of $\mathrm{RBF}$.

\section{RIFIRIN(1S ANI) NOTIS}

1. Alm. A.. and Bill. A. The oxygen supply w the retuna. II. Lffects of high intraocular presure and of increased arteral carbon doxide tension on uveal and retunal blosd thew in cats Acta Phrstol. Scand. $84: 3(6,11972)$

2. Alm. A... and Bill. A. Ocular and optic nerve hlond flow at normal and increased intra-ocular pressures in monkers (macacal irus): studs with radioactively labelled morospheres includeng liou determinattens in bran and some other tissues Ixp live Res. 15: 15 (1973)

3 Buckberg. (i. D). Luch. J. (.. Payne. I) B.. Hotfman. J. I. I... Archie. J. P. and

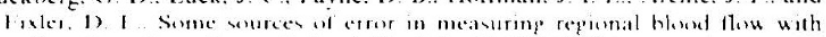
radioactive microspheres. J. Appl. Phwiol. 3/: $59 x(197)$ ).

4. (ain. S. M: Oxven delivers and uptake in dog during anemat and hypoxic hypoxia. J Appl Physwl., t2: 22x (1977).

5. Datues (i. S Fetal and Neonatal Physologes. Fearbook of Medocal Publishers. (hicage, lor,

6. Dollers. ( I.. Bulputt. ( . J., and kisherer. 1. M. Oxven suppls to the retina from the retinal and chorosdal circulations at normal and increased arteral uxygen tensions. Invest. Ophthalmol. \&: $58 \times(196,2)$.

7. Eperon, (i., Johnson. M.. and Nuble. J. R. The effect of arterial P() on relatue retinal blosd flow in monkess. Invest. (Ophihalmol. 14.342 (1975).

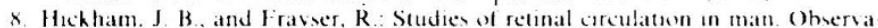
thons on vesel dameter, arterosenous oxygen difference and mean curculation tume. (irculation. 23, 302 (1966).

9. James. L. S. and Lanman. J. T. Histery of axyen theraps and retonlental tihroplasiat Pediatrics, $5-591$ (1976)

11). Jones, M. D. Jr. Sheldon. R. E., Peeters, 1. I... Mahousho, I. I... and Meschat (i.: Regulation of cerebral blood thu in the wine fetus am. J Physol. 235 $1162(147 x)$.

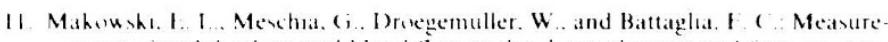

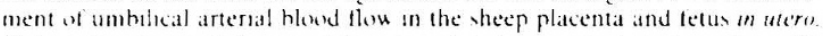

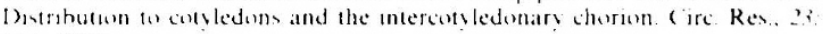
$023(19(6)$ )

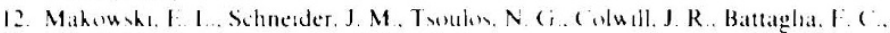

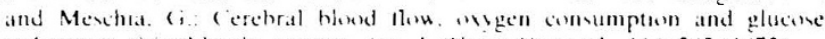

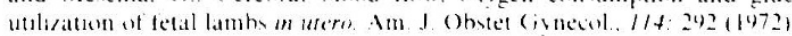

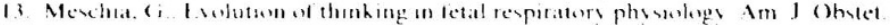
(ivnecol. liz sike (1978).

14. Peeters. 1. I. H. Fetal hlond llou at varous levels of oxgen. A studs in at

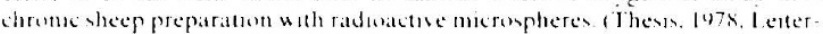
Nipels, B. V.. Matstreht. The Netherlands)

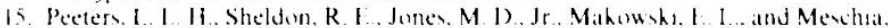

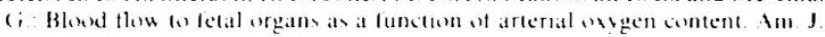

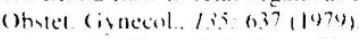

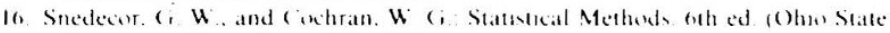
l'merests Press. Ames. ()H. 1976)

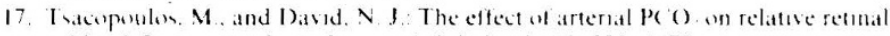

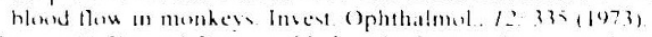

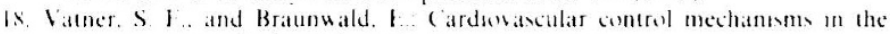

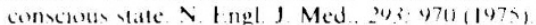

19. Warten. I) J. and ledongham. J. (i (i Meavurement al cardate antput distrhutwon using merospheres. Some practical and theoretcal comsderatums.

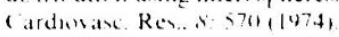

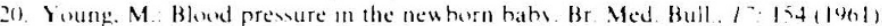
21. Expert statistcal assostance was prosided ho Mrs. N Peer and Mr. J Mulder of

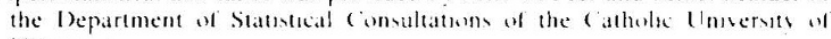
Nijmegen.

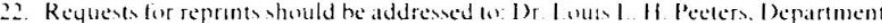

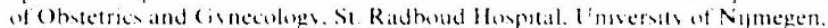
(ieere cironteplem Zund 14. Nijmegen. The Netherlands.

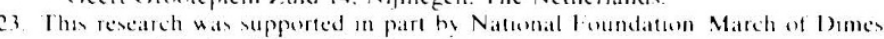
graml 1-302. be Puhle Healeh Service Research grant H1)-601781. and by

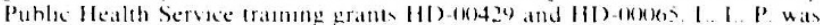
supported by a grant of the Stichting "1)e Drie Lichten." The Ilague. The Netherland.

24. Recerved for publacatson August 17. 1974

25. Accepted firs publicallon December 3. 1979

\section{APPINIDIX}

( NCIIATION OF THI PIR( NTIII IRROR ANI) THII

PIRCINTA(iE ()F INTRA-ANIMAI VARIATION IXPIAINII) BY A

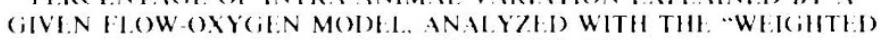
I. ASI-SQL ARES MITHOI)"

(stochastic variables are underlined)

$$
y_{11}=\mu+a_{1}+\beta \cdot f\left(\gamma, x_{11}\right)+e_{11} \quad\left(i=1, \cdots, N: j=1, \cdots, N_{1}\right)
$$

where $N=$ number of animals; $N_{1}=$ number of experiments in the $i^{\text {th }}$ animal.

$$
\sum_{1-1}^{N} \alpha_{1}=0
$$

where $y_{11}=$ blood flow measurement in the $j^{\text {th }}$ experiment of the $i^{\text {th }}$ animal: $\mu=$ a constant equal for all animals; $\alpha_{1}=$ additive effect due to the $i^{\text {th }}$ animal: $\beta, \gamma=$ regression coefficients assumed to be the same for each animal: $x_{11}=$ value for $\left[\mathrm{O}_{2}\right]_{\text {, }}$ in the $\mathrm{j}^{\text {th }}$ experiment of the $i^{\text {th }}$ animal; $f\left(\gamma, x_{11}\right)=$ function of $x_{11}$ and $\gamma\left\{e \cdot g . f\left(\gamma, x_{11}\right)=\right.$ $1 / \mathrm{x}_{11}$, or $\mathrm{f}\left(\gamma, \mathrm{x}_{11}\right)=\mathrm{e}: \mathrm{x}_{11}$. or $\left.f\left(\gamma, \mathrm{x}_{11}\right)=\left(\ln \mathrm{x}_{11}+\gamma\right) / \mathrm{x}_{11}\right\}: \mathrm{e}_{11}=$ error term with expectation zero and standard deviation proportional to the expectation of $y_{11}$.

The observed value for $y_{11}$ and not the expected term of $y_{11}$ is substituted for the error term $\varepsilon_{11}$ in the model above.

In this model, estimates $\hat{\mu}, \hat{\alpha}_{1}, \hat{\beta}$, and $\dot{\gamma}$ of respectively, $\mu, \alpha_{1}, \beta$. and $\gamma$ were determined in such a way that

$$
\sum_{1-1}^{N} \sum_{1-1}^{N}\left[\frac{y_{11}-\left\{\mu+\alpha_{1}+\beta \cdot f\left(\gamma \cdot x_{11}\right)\right\}}{y_{11}}\right]^{:}
$$

was minimal.

$$
\text { Let } \quad S_{m+1}=\sum_{1-1}^{N} \sum_{i=1}^{N}\left[\frac{y_{11}-\left[\hat{\mu}+\dot{a}_{1}+\hat{\beta} \cdot \dot{f}\left(\dot{\gamma} \cdot x_{11}\right)\right]}{y_{11}}\right]^{2}
$$

The percentile error was determined as follows:

$$
\sqrt{\frac{S_{m+1}}{d . f}} \times 10\left(0 ; \quad\left(d f=\sum_{i=1}^{N} N_{1}-p\right)\right.
$$


where $p=\nearrow N+1$, in case of one regression coefficient $(\beta), \ldots, \cdots N$

$\mathrm{N}+2$, in case of two regression coefficients $(\beta$. y).

If it could be assumed that blood flow was independent of $\left[\mathrm{O}_{2}\right.$. (thus $\beta=0$ ). estimates $\hat{\mu}_{1}$ for $\mu+a_{1}$ could be determined in such a way that

$$
\sum_{i=1}^{N} \sum_{i=1}^{N}\left[\frac{y_{11}-\left\{\mu+a_{1}\right\}}{y_{11}}\right]^{2}
$$

was minimal.

Let: $\mu_{1}=\mu+\alpha_{1}$, then the function:

$$
g\left(\mu_{1}, \cdots, \cdots, \mu_{N}\right)=\underset{1}{N} \sum_{1}^{N}\left[\frac{y_{11}-\mu_{1}}{y_{11}}\right]
$$

thus $\quad \dot{\mu}_{1}=\frac{\sum_{1-1}^{N} 1 / y_{11}}{\sum_{1=1}^{N}\left(1 / y_{11}\right)^{2}}$

$$
\text { L.e1 } S=\sum_{1}^{N} \sum_{1}^{N} N_{1}^{N}\left[\frac{y_{11}-\left[\sum_{1=1}^{N}\left(1 / y_{11}\right) / \sum_{1}^{N}\left(1 / y_{11}\right)\right]}{y_{11}^{\prime}}\right]
$$

Remark $0 \leq \mathrm{S}_{\text {mm }} \leq \mathrm{S}$

A measure of the explained variation in hlood flow values by a given flow-oxygen function was obtained by

would be minimal when the partial derivatives $\frac{\partial g}{\partial \mu_{1}}=0$ for $\mathrm{i}=1$.

$$
\text { I)( }\left[\frac{\mathrm{S}-\mathrm{S}_{\text {ma! }}}{\mathrm{S}}\right] \text { \%; }
$$

Copyrght : 1980) International Pedatre Research foundatton. Inc

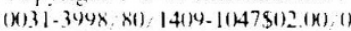

